\title{
Effect of annual use of pesticides on soil microorganisms and sugar beet yields
}

\author{
HELVI HEINONEN-TANSKI ${ }^{1}$, PAAVO SIMOJOKI ${ }^{2}$, KYÖSTI RAININKO ${ }^{3}$, \\ NILS NUORMALA ${ }^{3}$ and RIITTA SILVO ${ }^{4}$
}

1 University of Kuopio, Department of Environmental Engineering, POB 6, SF-70211 Kuopio, Finland

2 Agricultural Research Centre, Central Finland Research Station, SF-41340 Laukaa, Finland

${ }^{3}$ Sugar Beet Research Centre, SF-25170 Kotalato, Finland

4 Water Protection Association of Saimaa Region, Hietakallionkatu 2, SF-53850 Lappeenranta, Finland

\begin{abstract}
Sugar beet is often cultivated for several years on the same fields, using many pesticides. We have therefore studied the effects of a pesticide programme on soil microorganisms and sugar beet yields in Perniö and Laukaa. The pesticides in use were thiram, hymexazol, dimethoate, phenmedipham and metamitron and, in Laukaa only, alloxidim-Na. Pesticides were used either in the normal doses or at $150 \%$ of the normal dose.

The normal doses of pesticide application had a favourable effect on sugar beet yields in both experiments. The sugar yield was higher in plots with the normal pesticide doses than in the control plots. The overdoses increased neither the sugar beet yields nor the sugar yields as compared to the normal plots. The soil microorganisms were affected by pesticides in some but not in all cases. The most sensitive were the ureolytic microorganisms and the dehydrogenase activities.
\end{abstract}

Index words: Alloxidim-Na, dimethoate, hymexazol, metamitron, phenmedipham, thiram, total number, spore-forming aerobes, ureolytics, dehydrogenase, nitrification, cellulolysis

\section{Introduction}

The cultivation of sugar beet nowadays requires the use of pesticides. Sugar beet also requires a very good soil structure so that the developing roots get water and nutrients but do not lack air. For a long time in spring and early summer the soil is covered by crops only partly, and is therefore exposed to erosion. The pressure of the heavy machines in use in- 
creases the risk of soil tightening which has also been found in Finnish sugar beet fields (ErJala \& RaininKo, 1985; RaININKo, 1988). Soil microorganisms which form soil aggregates have favourable effects on the soil structure and microorganisms of sugar beet soil are therefore particularly important. The microorganisms are also the most important factors for the decomposition and forming of nutrients available for plants and in the degradation of pesticides which could leave residues.

The effects of individual pesticides as well as some pesticide programmes on the soil biology of sugar beet fields have been studied (Pestemer \& Malkomes, 1983), but the pesticides used in these experiments are not used in Finland. The aim of our study was to determine the possible microbial response to pesticides in Finland. The pesticide doses for the present study were selected to correspond a) to the normal, recommended dose and b) to $150 \%$ of this dose, because slight overdoses (or underdoses) of pesticides may be typical resulting from uneven distribution or broken spraying machines, which is rather common in Finland (LuOMA \& LAvonen, 1987).

Seed dressing compounds thiram and hymexazol are fungicides. This mixture has been found to control effectively the damping-off of sugar beet (VESTBERG et al. 1982).

Hymexazol is known to affect, in particular, Fusarium, Aphanamyces, Pythium, Corticium (Pesticide Manual, 1979) Mortierella, some Phytophtora (Tsao \& Guy, 1977), Alternaria, Botrytis, and Phoma betae (VURBANOv et al. 1984). The effects of hymexazol on non-target soil microbes have been described very sporadically. Hymexazol only in high concentrations inhibits Saccharomyces, Pseudomonas (Kamimura et al. 1976), red clover rhizobia (HEINONEN-TANSKI et al. 1982) and various phytopathogenic bacteria (TомITA et al. 1975; Oros et al. 1983). The Bengal gram rhizobia studied by GARG et al. (1981) were more sensitive to hymexazol than the above mentioned microbes. Hymexazol is degraded by soil microorganisms to carbon di- oxide, acetoacetamide and oxazolone (NAKANISHI et al. 1974).

As a fungicide, thiram is known to reduce the fungal activity of soil (ANDERSON et al. 1981; Hickisch et al. 1984) and the numbers of some bacteria, e.g. nitrogen-fixers (reviewed by Torstensson, 1979). Thiram application increases the number of phosphate mobilizing microbes in soil (WAINWRIGHT \& SOWDEN, 1977).

The effect of dimethoate on soil microbes is poorly known, but may be short-lived (Congregado et al. 1979) owing to the relatively rapid degradation of dimethoate (BROBASMUSSEN et al. 1969).

Phenmedipham in normal doses decreases the biological activity of some sugar beet soils for a short time (BELlinck \& MAYAUDON, 1978; Verstraete et al. 1979) and inhibits the number of Azotobacterium (SIMONSylvestre \& Beaumont, 1982). On the other hand, it increases cellulose degradation and ammonification (SimON-Sylvestre, 1979). The effects of phenmedipham on nitrification may be inhibitory or stimulatory, depending on soil type (SimON-Sylvestre, 1979; Verstraete et al. 1979). The oxidation of ammonia to nitrite is less sensitive than the oxidation of nitrite to nitrate (RATNAYAKE \& Audus, 1978), which can result in the enrichment of nitrite in soil. Excessive concentrations of phenmedipham strongly inhibit soil nitrification (TENA et al. 1984).

As a general conclusion, the effects of phenmedipham are less negative on soil microorganisms than those of metamitron or some other herbicides used with sugar beet (Verstraete et al. 1979). Metamitron can stimulate urease activities in soil, but it has only minor effects on phosphatase, on the numbers of various microbial groups (VOETS et al. 1977; GADKARI, 1984), and on nitrogen and carbon transformation (MALKOMES, 1987). The nitrogen fixation of some cyanobacteria is inhibited by metamitron (GADKARI, 1987).

Alloxidim-Na degraded microbiologically rapidly in two sandy soils at $25^{\circ} \mathrm{C}$ (ONO et al. 
1984). The half-lives were approximately 56 days. Many unidentified and identified metabolites (including $\mathrm{CO}_{2}$ ) were found. In Swedish experiments, however, alloxidim-Na could still be found up to $2-3$ months after the spring spraying (NILSsON, 1984). The persistence was higher in northern Sweden than in southern Sweden. Alloxidim-Na has a slight inhibitory effect on pea nodulation (BEBB et al. 1985), but no effect on the degradation of herbicide benazolin (KosTowsKA et al. 1982).

\section{Materials and methods}

The sugar beet (Salohill) has been cultivated in loam containing $10.7 \%$ organic matter in
Laukaa $\left(62^{\circ} 28^{\prime} \mathrm{N}, 25^{\circ} 56^{\prime} \mathrm{E}\right)$ and in silty clay containing $8.7 \%$ organic matter in Perniö $\left(60^{\circ} 17^{\prime} \mathrm{N} 23^{\circ} 7^{\prime} \mathrm{E}\right)$ in $1982-1985$. The seeding $\left(10^{5}\right.$ seeds/ha) was done in Perniö by sown-to-stand by $15 \mathrm{~cm}$ seed spacing with simultaneous fertilizing (ERJALA \& RAININKO, 1985; RaININKO, 1988).

The soils are described in Table 1 . The trials were carried out in four parallel plots $(9 \mathrm{~m} \times$ $12 \mathrm{~m}$ in Laukaa and $14.4 \mathrm{~m} \times 36 \mathrm{~m}$ in Perniö). The control plots were not dosed with pesticides, the weeds were hand-weeded in the second weeks of June and July. The pesticides were applied at normal recommended dosages or $150 \%$ of the normal dosages. The agricultural operations and sampling schedules were

Table 1. Properties of the soils at the beginning of the trials.

\begin{tabular}{|c|c|c|c|c|c|}
\hline & $\mathrm{pH}$ & $\mathrm{K} \mathrm{mg} / 1$ & P mg/l & $\mathrm{Mg} \mathrm{mg} / 1$ & $\mathrm{Ca} \mathrm{mg/l}$ \\
\hline Laukaa & 6.2 & 108 & 14 & 142 & 1708 \\
\hline \multirow[t]{2}{*}{ Perniō } & 6.7 & 241 & 21 & 614 & 4422 \\
\hline & Sand $\%$ & Silt $\%$ & Clay \% & & \\
\hline Laukaa & 30 & 43 & 27 & & \\
\hline Perniō & 17 & 27 & 55 & & \\
\hline
\end{tabular}

Table 2. Agricultural schedule and sampling times.

\begin{tabular}{|c|c|c|c|}
\hline Time & Control plots & $\begin{array}{l}\text { Normal pesticide } \\
\text { dose }\end{array}$ & $\begin{array}{l}150 \% \text { of the normal } \\
\text { pesticide dose }\end{array}$ \\
\hline May & sampling & sampling & sampling \\
\hline Late May & seeding & $\begin{array}{l}\text { seeding }+ \text { seed dressing with } \\
6.8 \mathrm{~g} / \mathrm{ha} \text { thiram }+17.5 \mathrm{~g} / \mathrm{ha} \\
\text { hymexazol }^{2}\end{array}$ & 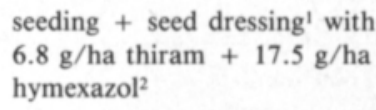 \\
\hline Early June & - & $\begin{array}{l}450 \mathrm{~g} / \text { ha phenmedipham }+ \\
240 \mathrm{~g} / \text { ha dimethoate }\end{array}$ & $\begin{array}{l}675 \mathrm{~g} / \text { ha phenmedipham }+ \\
360 \mathrm{~g} / \text { ha dimethoate }\end{array}$ \\
\hline Middle of June & sampling & sampling & sampling \\
\hline Late June & - & $\begin{array}{l}450 \mathrm{~g} / \text { ha phenmedipham }+ \\
2800 \mathrm{~g} / \text { ha metamitron }+ \\
240 \mathrm{~g} / \text { ha dimethoate }\end{array}$ & $\begin{array}{l}675 \mathrm{~g} / \text { ha phenmedipham }+ \\
4200 \mathrm{~g} / \text { ha metamitron }+ \\
360 \mathrm{~g} / \text { ha dimethoate }\end{array}$ \\
\hline Early July & - & $\begin{array}{l}471 \mathrm{~g} / \text { ha phenmedipham }+ \\
1500 \mathrm{~g} / \text { ha alloxidim- } \mathrm{Na}^{3}\end{array}$ & $\begin{array}{l}707 \mathrm{~g} / \text { ha phenmedipham }+ \\
2250 \mathrm{~g} / \text { ha alloxidim }-\mathrm{Na}^{3}\end{array}$ \\
\hline Early Aug. & sampling & sampling & sampling \\
\hline Early Sep. & sampling & sampling & sampling \\
\hline Oct. & harvesting & harvesting & harvesting \\
\hline
\end{tabular}

$150 \%$ of the normal dosage in Laukaa

${ }^{2}$ not in 1982 in Laukaa

${ }^{3}$ alloxicim-Na only in Laukaa 
done as needed; they are presented in Table 2 . In some cases dimethoate and a second herbicide treatment with phenmedipham and metamitron were applied before the second sampling. Alloxidim-Na was used only in Laukaa. No hymexazol was used in 1982 in Laukaa.

The sub-samples, to a depth of $3 \mathrm{~cm}$, were collected from five parts of the plots, bulked and mixed. The samples were never taken from the area within $1 \mathrm{~m}$ of the border of each plot. The microbiological inoculations were made on the sampling day. The soils were kept at $5^{\circ} \mathrm{C}$ for the next day for the dehydrogenase determinations. For the determination of the nitrification activity, the soil samples were airdried at room temperature for 3-10 days.

The number of "total" microorganisms were determined on TAYLOR's (1951) agar. The numbers of spore-forming aerobes were determined on agar of FENCHEL and HeMMINGSEN (1974) after destroying the non-sporing microorganisms by heat-treatment at $80^{\circ} \mathrm{C}$ for $20 \mathrm{~min}$. The ureolytics were determined by the MPN-technique in the CHRISTENSEN
(1946) medium. The incubations were kept at $15^{\circ} \mathrm{C}$ for $3-4$ weeks.

The determination of dehydrogenase has been described by MetTÄLÄ et al. (1982) and the nitrification by HEINONEN-TANSKI et al. (1985). The cellulose decomposition was determined by the polyester-bag method, following the weight loss of filter paper $(5 \mathrm{~g}$, Schleicher \& Schüll 604) buried to a depth of $2 \mathrm{~cm}$ for three to four months. The papers were washed carefully, dried at room temperature and weighed.

The $t$-tests and paired $t$-tests were performed by using natural log transformations of the microbial groups at all the sampling times (14) and both of the places (2) and treatments (2).

\section{Results}

The soil microbial results are presented in Table 3, giving the means for the microbial numbers and activities during the entire experimental time. The most significant statistical differences in Perniö were found for de-

Table 3. Geometrical mean of microbial numbers and the arithmetic means for dehydrogenase, nitrification and cellulolysis activities in 1982-1985 in control plots, plots with the normal pesticide dosage and plots with $150 \%$ of the normal pesticide dosage.

\begin{tabular}{lccc}
\hline & \multicolumn{3}{c}{ Laukaa experiment } \\
\cline { 2 - 4 } & $\begin{array}{c}\text { Control } \\
\text { plots }\end{array}$ & $\begin{array}{c}\text { Normal } \\
\text { pesticide }\end{array}$ & $\begin{array}{c}150 \% \text { of the } \\
\text { normal }\end{array}$ \\
\hline Total number $\times 10^{7}$ & 41 & 36 & 43 \\
Spore-forming aerobes $\times 10^{4}$ & 83 & 85 & 70 \\
Ureolytics $\times 10^{4}$ & 77 & $57^{*}$ & $52^{* *}$ \\
Dehydrogenase TPF $\mu \mathrm{g} / \mathrm{g}$ & 80.6 & $73.8^{*}$ & 74.1 \\
nitrification $\mathrm{NO}_{3}-\mathrm{N} \mu \mathrm{g} / \mathrm{g}$ & 73.8 & 77.6 & 71.5 \\
Cellulolysis $\%$ & 40.5 & 41.9 & 40.2 \\
\hline & \multicolumn{3}{c}{} \\
\cline { 2 - 4 } & Control & Perniö experiment & $150 \%$ of the \\
& plots & Normal & pesticide \\
\hline Total number $\times 10^{7}$ & 22 & 20 & 25 \\
Spore-forming aerobes $\times 10^{4}$ & 80 & 81 & 76 \\
Ureolytics $\times 10^{4}$ & 12 & 11 & 11 \\
Dehydrogenase TPF $\mu \mathrm{g} / \mathrm{g}$ & 51.5 & $46.8^{*}$ & $46.0^{* * *}$ \\
Nitrification $\mathrm{NO}_{3}-\mathrm{N} \mu \mathrm{g} / \mathrm{g}$ & 119 & 126 & 32.0 \\
Cellulolysis $\%$ & 36.2 & 34.3 & \\
\hline
\end{tabular}

$* * \mathrm{P}<0.01$ and $* \mathrm{P}<0.05$ 
hydrogenase activity $(\mathrm{P}=0.021$ in paired $t$ tests for the plots with normal pesticides and $\mathrm{P}=0.009$ for the plots with $150 \%$ pesticide dosage and in Laukaa for dehydrogenase activity $(\mathrm{P}=0.036$ for plots with normal pesticide dosage $)$ and for ureolytics $(\mathrm{P}=0.035$ for the normal pesticide dosage and $\mathrm{P}=0.006$ for the $150 \%$ pesticide dosage).

The differences between microbial numbers or activities during separate experiments and sampling times were statistically significant $(\mathrm{P}<0.05)$ in some cases $(56$ cases together in both places and treatments). In these cases the microbial numbers or activities of the pesticide-treated plots were lower than in the controls nine times in Laukaa and ten times in Perniö, and higher three times in Laukaa and twice in Perniö. Both the normal doses and the overdoses caused these effects. The effects were temporary. The dehydrogenase activity tests differed significantly eleven times and the number of the ureolytics five times.

The sugar beet yields in Laukaa and Per- niö are presented in Table 4 . The beet and sugar yields in plots with normal the pesticide dosage were higher than the control although the difference was not statistically significant. The yields in the plots with the $150 \%$ pesticide dosage were similar or less than in the plots with normal pesticide dosage in Perniö but similar or higher in Laukaa. The dry weights of top yields were measured only in Laukaa. The top yields were statistically significantly $(\mathrm{P}<0.05)$ higher in pesticide-treated plots than in the controls. No symptoms of damage caused by pesticides or diseases were found.

\section{Discussion}

The degradation of metamitron used in relatively high doses depends very much on temperature. A decrease of $10^{\circ} \mathrm{C}$ retarded the degradation to $1 / 4$ of the degradation rate at higher temperature (FÜHR \& MITTELSTAEDT, 1979), whereas a few warm days did

Table 4. Sugar beet (t/ha) and sugar yields $(\mathrm{kg} / \mathrm{ha})$ and Laukaa dry matter of tops $(\mathrm{kg} / \mathrm{ha})$ in control plots, plots with the normal pesticide dosage and plots with $150 \%$ of normal pesticide dosage. $d m=$ dry matter. $n . d .=$ not determined.

\begin{tabular}{|c|c|c|c|c|c|c|c|c|c|}
\hline \multirow[t]{3}{*}{ Year } & \multicolumn{9}{|c|}{ Laukaa experiment } \\
\hline & \multicolumn{3}{|c|}{ Control plots } & \multicolumn{3}{|c|}{ Normal pesticide } & \multicolumn{3}{|c|}{$150 \%$ of the normal } \\
\hline & $\begin{array}{l}\text { Beets } \\
\text { t/ha }\end{array}$ & $\begin{array}{l}\text { Sugar } \\
\mathrm{kg} / \mathrm{ha}\end{array}$ & $\begin{array}{l}\text { Top dm } \\
\mathrm{kg} / \mathrm{ha}\end{array}$ & $\begin{array}{l}\text { Beets } \\
\text { t/ha }\end{array}$ & $\begin{array}{l}\text { Sugar } \\
\mathrm{kg} / \mathrm{ha}\end{array}$ & $\begin{array}{l}\text { Top dm } \\
\mathrm{kg} / \mathrm{ha}\end{array}$ & $\begin{array}{c}\text { Beets } \\
\text { t/ha }\end{array}$ & $\begin{array}{l}\text { Sugar } \\
\mathrm{kg} / \mathrm{ha}\end{array}$ & $\begin{array}{c}\text { Top dm } \\
\mathrm{kg} / \mathrm{ha}\end{array}$ \\
\hline 1982 & 2.0 & 308 & 500 & 5.8 & 481 & 1350 & 6.7 & 1028 & 1540 \\
\hline 1983 & 33.1 & 6424 & 3090 & 40.2 & 7833 & 5580 & 42.5 & 7648 & 6180 \\
\hline 1984 & 9.2 & n.d. & 1450 & 8.0 & n.d. & 2090 & 13.7 & n.d. & 2800 \\
\hline 1985 & 24.5 & n.d. & 4260 & 30.5 & n.d. & 6790 & 30.7 & n.d. & 7780 \\
\hline \multirow[t]{2}{*}{1986} & 22.5 & n.d. & 3170 & 20.2 & n.d. & 4670 & 24.1 & n.d. & 4860 \\
\hline & 100 & (100) & 100 & 115 & (129) & 165 & 129 & (129) & 187 \\
\hline \multirow[t]{3}{*}{ Year } & \multicolumn{9}{|c|}{ Perniō experiment } \\
\hline & \multicolumn{3}{|c|}{ Control plots } & \multicolumn{3}{|c|}{ Normal pesticide } & \multicolumn{3}{|c|}{$150 \%$ of the normal } \\
\hline & & $\begin{array}{l}\text { Beets } \\
\mathrm{t} / \mathrm{ha}\end{array}$ & $\begin{array}{l}\text { Sugar } \\
\mathrm{kg} / \mathrm{ha}\end{array}$ & & $\begin{array}{l}\text { Beets } \\
\text { t/ha }\end{array}$ & $\begin{array}{l}\text { Sugar } \\
\mathrm{kg} / \mathrm{ha}\end{array}$ & & $\begin{array}{l}\text { Beets } \\
\text { t/ha }\end{array}$ & $\begin{array}{l}\text { Sugar } \\
\mathrm{kg} / \mathrm{ha}\end{array}$ \\
\hline 1982 & & 33.2 & 5169 & & 35.5 & 5481 & & 34.0 & 5220 \\
\hline 1983 & & 44.3 & 7262 & & 45.4 & 7395 & & 43.5 & 7065 \\
\hline 1984 & & 16.3 & 2578 & & 26.3 & 3274 & & 19.4 & 3063 \\
\hline \multirow[t]{2}{*}{1985} & & 25.3 & 4160 & & 26.2 & 4341 & & 30.5 & 4065 \\
\hline & & 100 & 100 & & 107 & 106 & & 102 & 101 \\
\hline
\end{tabular}


not markedly increase the degradation of metamitron. Thus FüHr and MittelstaedT (1979) assumed that there is practically no degradation of metamitron in the German climate from November to March. In the climatic conditions of Finland, the degradation of metamitron may be even slower and limited to a shorter period. Allen and WAlKer (1987) also found that the degradation of metamitron depends positively on the sand percentage and negatively on the silt and clay percentages of soil. Thus we can assume that the degradation of metamitron may have taken place more rapidly in Laukaa than in Perniö due to the coarser soil texture in Laukaa. The residues of metamitron (not measured) may still have been considerable, possibly reducing the sugar and sugar beet yields, especially in plots administered $150 \%$ of the normal herbicide doses in the Perniö experiments. Also the sugar percentage was reduced in Laukaa in pesticide-treated plots in 1983; the sugar yields of 1982 were so low in Laukaa that conclusions are difficult to draw. Unfortunately, the sugar content was not measured lately in the Laukaa experiments.

Alloxidim-Na may have degraded well also in the Laukaa experiments giving $\mathrm{CO}_{2}$ and the free and humus-bound residual degradation products found in Japanese outdoor experiments (ONO et al. 1984), although this may not have occured in a few days but in a few weeks or months, as in Sweden (NILSSON, 1984).

The normal application of pesticides had a favourable effect on sugar beet and sugar yields in this trial. But the overdoses of pesticides, $150 \%$ of the normal gave only the same or slightly lower sugar yields than the normal doses during the years tested. According to this result overdoses of sugar beet pesticides, especially herbicides, should be avoided.
All the statistically significant effects caused by pesticides on soil microorganisms, both stimulative or inhibitive, must be considered to be unfavourable because they disturb the dynamic equilibrium of the soil microorganisms.

Often these effects can be regarded as a symptom of overly long-lasting residues of pesticides or their degradation results. Many pesticides with "unusual" chemical structure, e.g. with halogenation, aromatic or triazine rings, are degraded by cometabolism. Cometabolic degradation requires another carbon source and is the joint work of many microorganisms. Thus the degradation of metamitron is cometabolic according to the results of FüHR and MrTTELSTAEDT (1979) and ENGELHARDT et al. (1982). The cometabolic degradation can be accelerated by increasing the general microbial activity (TORSTENSSON \& STEnström, 1986). The general microbial activity can be increased, for instance by adding reasonable amounts of mineral fertilizers or by application of crop rotation (METTÄLÃ et al. 1982), or by adding organic compounds (CAMPBEll, 1985). Rotation with ley caused a very great increase in microbial activity in Finnish clay soil (HeINONEN-TANSKI, 1986).

To be sure of the high general microbial activity necessary also for the degradation of pesticides and for good soil structure, knowledge is needed about practical methods for increasing microbial activity. The possible methods could be either the use of sugar beet tops and other organic matter as fertilizers or suitable and economical rotation.

Acknowledgements. We wish to thank Ms. Pirjo Halonen M. Sc. for statistical calculation of the microbial results, Ms. Sevastiana Ruusamo M. A. for correcting the English language and many students for their microbial laboratory work. 


\section{References}

Allen, R. \& W Wlker, A. 1987. The influence of soil properties on the rates of degradation of metamitron, metazachlor and metribuzin. Pestic. Sci. 18: 95-111.

Anderson, J.P.E., Armstrong, R.A. \& Smith, S.N. 1981. Methods to evaluate pesticide damage to the biomass of the soil microflora. Soil. Biol. Biochem. 13: 149-153.

Bebb, J.M., Greaves, M.P. \& Richardson, W.G. 1985. The side effects of alloxidim sodium, sethoxydim, acifluorfen and fluazifop-butyl on legume growth and nodulation. Weed Res. Org. Technic. Rep. 81: 1-20.

Bellinck, C. \& Mayaudon, J. 1978. Influence du phenmediphame et dérivés sur l'activité biologique et le nombre de microorganismes des sols frais. Rev. Ecol. Biol. Sol 15: 435-444.

Bro-Rasmussen, F., Noddegaard, E. \& Voldum-Clausen, K. 1969. Comparison of the disappearance of eight organophosphorus insecticides from soil in laboratory and in outdoor experiments. Pestic. Sci. 1: 179-182.

CAmprell, R. 1985. Plant Microbiology. Edward Arnold. pp 191.

Christensen, W.B. 1946. Urea decomposition as a means of differentiation of Proteus and paracolon cultures from each other and from Salmonella and Shigella types. J. Bact. 52: 461-466.

Congregado, F., Simon-Pujol, D. \& Juarez, A. 1979. Effect of two organophosphorus insecticides on the phosphate-dissolving soil bacteria. Appl. Environm. Microbiol. 37: 169-171.

Engelhardt, G., Ziegler, W., Wallnofer, P.R., Jarczyk, H.J. \& OehlmanN, L. 1982. Degradation of triazinone herbicide metamitron by Arthrobacter sp. DSM 20389. J. Agric. Food Chem. 30: 278-282.

ErJala, M. \& Raininko, K. 1985. Sådd av sockerbetan på lerjord med en körning. Betan 1985: 13-17.

Fenchel, T. \& Hemmingsen, B.B. 1974. Manual of microbial ecology. Akademisk Forlag, Copenhagen.

Fohr, F. \& Mittelstaedt, W. 1979. Effect of varying soil temperatures on the degradation of methabenzthiazuron, isocarbamid and metamitron. Zeitschr. Pflanzenern. Bodenk. 142: 657-668.

GADKARI, D. 1984. Influence of the herbicide Goltix on extra-cellular urease and phosphatase in suspended soil. Zentrbl. Mikrobiol. 139: 415-424.

- 1987. Influence of the photosynthesis-inhibiting herbicides Goltix and Sencor on growth and nitrogenase activity of Anabaena cylindrica and Nostoc mucorum. Biol. Fertil. Soils 3: 171-177.

Garg, F.C., Tauro, P., Mishra, M.M. \& Grover, R.K. 1981. Effect of fungicides on growth and DNA, RNA and protein anabolism of a Rhizobium sp. Ann. Microbiol. 132 B: 231-239.

Heinonen-TAnski, H. 1986. Biologisk aktivitet i jorden. Odlingssystem och växtfoljder med huvudvikt på alternativ odling. Nordiska Jordbruksforskarnas förening. Seminarium 106: $16(1-5)$.

-, Oros, G. \& Kécskés, M. 1982. The effect of soil pesticides on the growth of red clover rhizobia. Acta. Agr. Scand. 32: 283-288.

-, Rosenberg, C., Siltanen, H., Kilpi, S. \& Simojoki, P. 1985. The effect of the annual use of pesticides on soil microorganisms, pesticide residues in the soil and barley yields. Pestic. Sci. 16: 341-348.

Hickisch, B., Machulla, G. \& Móller, G. Jun 1984. Laborversuche: Prüfprogramm, Ergebnisse der Prüffaktoren Bakterien- und Pilzbesiedlungsdichte, Dehydrogenaseaktivităt und Bodenatmung nach mehrmaliger Applikation. Zentrbl. Mikrobiol. 39: 119128.

Kamimura, S., Akutsu, M. \& TаKahi, Y. 1976. Adsorption of hymexazol by sensitive and insensitive microorganisms. Ann. Phytopath. Soc. Japan 42: 204-215.

Kostowska, B., Kramer, H. \& Piasecka-Grzeszek, A. 1982. Wplyw terminu stosowania preparatu cresopur na pozostaosci benazoliny w glebie i rzepaku ozimym. Pamiertnik Pulawski 78: 178-188.

Luoma, T. \& LAvonEN A. 1987. Maatiloilla käytettävien kasvinsuojeluruiskujen tekninen kunto. 8. Kasvinsuojelu- ja tuhoeläinpäivă 6-10.

Malkomes, H.-P. 1987. Einfluss von 2 Herbiziden auf den Kohlenstoff- und Stickstoffumsatz im Boden unter Laborbedingungen bei unterschiedlicher Stickstoffdüngung. Zentrbl. Mikrobiol. 142: 569-579.

Mettālä, A., Koponen, M., Pirinen, H. \& Korkman, J. 1982. The effect of fertilization and crop rotation on soil chemical and biological properties in field trials on a clay soil in Southern Finland. J. Scient. agric. Soc. Finland 54: 331-344.

NaKanishi, T., TAKAhI, Y. \& Tomita, K. 1974. Microbial conversion of hymexazol in soil. Ann. Phytopath. Soc. Japan 40: 383-391.

Nitsson, H. 1984. Persistence and mobility of herbicides in arable soil. Investigations in 1980-81. Klimatfaktorers inverkan på herbicidernas effekt. NJF seminarium 58: $302-310$.

Ono, S., Shiotani, H., Ishihara, K., Tokieda, M. \& SoEdA, Y. 1984. Degradation of the herbicide alloxidim-sodium in soil. J. Pestic. Sci. 9: 471-480.

Oros, G., Heınonen-TansKı, H. \& Kecskés, M. 1983. A CGA 64250 Rhizobium japonicum-gátló hatásának tanulmányozása labóratoriumi modellkisérletben. Agrokémia és Talajtan 32: 539-543.

Pestemer, W. \& Malkomes, H-P. 1983. Einfluss von Pflanzenschutzmitteln einer Zuckerrüben-Spritzfolge auf biologische Aktivităten und auf den Abbau von Chloridazon in Boden. I Freilandversuche. Weed Res. 23: 283-291.

Pesticide Manual, 1979. A World Compendium. The British Crop Protection. Ed. C.R. Worthing. 6th Ed. RAININKo, K. 1988. Seed bed preparation and simultane- 
ous placement of fertilizer at drilling in one operation to save costs and increase yield. I.I.R.B. 51st Winter Congress Proc. 23-32.

Ratnayake, M. \& Audus, L.J. 1978. Studies on the effects of herbicides on soil nitrification. Pestic. Biochem. Physiol. 8: 170-185.

Simon-Sylvestre, G. 1979. Effets de quelques pesticides sur la minéralisation de l'azote organique du sol, la nitrification et la cellulolyse. Ann. agron. 30: 265-279.

- \& Beaumont, A. 1982. Effets de quelques pesticides sur les azotobacters. Agrochim. 26: 157-166.

TAYLOR, C.B. 1951. The nutritional requirements of the predominant bacterial flora of the soil. Proc. Soc. appl. Microbiol. 14: 101-111.

Tena, M., Garrido, R. \& Magallanes, M. 1984. Sugar beet herbicides and soil nitrification. Soil Biol. Biochem. 16: 223-226.

Tomita, K., Ohata, K., Nakamura, N., Takahi, Y. \& TAKAOKA, K. 1975. Development and industrialization of Tachigaren, a soil fungicide. Research and Development in Japan awarded the Okochi Memorial Prize pp. 49-53.

ToRstensson, L. 1979. Bekämpningsmedlens inverkan på markens organismer. 2 Mikroorganismer. Naturvårdsverket, 1208: 1-152.

- \& Stenströ, J. 1986. "Basic" respiration as a tool for prediction of pesticide persistence in soil. Toxicity Assessment 1: 57-72.

TSAO, P.H. \& GuY, S.O. 1977. Inhibition of Mortierella and Pythium in a Phytophthora-isolation medium containing hymexazol. Phytopath. 67: 796-801.

Verstraete, W., Stryckers, J., Cadron, J., Van Himme, H. \& Buclke, R. 1979. Side-effects on the soil microbiota in beet crops - Evaluation of the 1977 results. Med. Fac. Landboww. Rijksuniv. Gent 44: $669-674$.

Vestberg, M., Tahvonen, R., Raininko, K. \& Nuorma. LA, N. 1982. Damping-off of sugar beet in Finland. II. Disease control. J. Scient. agric. Soc. Finland 55: $431-450$.

Voets, J.P., Angerosa Imas, M.O., Goddeeris, H. \& Verstraete, W. 1977. The influence of pyrazon, ethofumesate and metamitron on the soil microbiota. Acta Phytopath. Acad. Scient. Hung. 12: 31-39.

Vurbanov, V., Slavov, K. \& Slavchev, A. 1984. Fungicide treatment of coated sugar beet seeds. Plant Sci. 21: 90-96.

WaINWright, M. \& Sowden, F.J. 1977. Influence of fungicide treatment on $\mathrm{CaCl}_{2}$-extractable phosphorus and phosphate-solubilizing micro-organisms in soil. Plant Soil 48: 335-345.

Ms received

\section{SELOSTUS}

\section{Sokerijuurikkaan viljelyssä käytetyn torjunta- aineohjelman vaikutus maan mikrobeihin ja sokerijuurikkaan satoihin}

\author{
Helvi Heinonen-Tanski ${ }^{1}$, Paavo Simojoki ${ }^{2}$, \\ Kyösti Raininko ${ }^{3}$, Nils Nuormala ${ }^{3}$ \\ ja Riitta Silvo ${ }^{4}$ \\ 1 Teknisen ympäristöhygienian laitos, \\ Kuopion yliopisto \\ Pl 6, 70211 Kuopio \\ 2 Maatalouden tutkimuskeskus, \\ Keski-Suomen tutkimusasema, \\ 41340 Laukaa \\ ${ }^{3}$ Sokerijuurikkaan Tutkimuskeskus, \\ 25170 Kotalato \\ 4 Saimaan vesiensuojeluyhdistys, \\ Hietakallionkatu 2, \\ 53850 Lappeenranta
}

Sokerijuurikkaalla kảytetăăn nykyāăn lăhes sãănnőllisesti torjunta-aineita. Tässă työssă selvitettiin torjunta- aineohjelmien vaikutusta sokerijuurikasmaan mikrobistoon sekă sokerijuurikkaan satoon. Kenttăkokeet tehtiin savimaassa Perniőssă Sokerijuurikkaan Tutkimuskeskuksessa ja hiesumaasşa Laukaassa Maatalouden tutkimuskeskuksen Keski-Suomen tutkimusasemalla. Käytetyt torjunta-aineet olivat tiraamin ja hymeksasolin seos peittaukseen, dimetoaatti hyönteistorjuntaan sekä fenmedifaami, metamitroni ja vain Laukaassa alloksidiimi-Na rikkakasvien torjuntaan. Torjunta-aineita kăytettiin joko normaali, suositeltu mäără tai $150 \%$ tăstă. Tarkat torjuntaainemăărăt ja kăyttőjärjestely ilmenevăt taulukosta 2 . Vertailuruutujen rikkakasvit kitkettiin käsin eikä peittausta tai hyönteistorjuntaa tehty.

Sokerijuurikassadot lisääntyivăt torjunta-ainekäsittelystä, mutta yliannostus ei enäă lisännyt satoa normaalikäsittelyyn verrattuna. Perniön kokeessa sokerisato oli yliannoksen saaneissa ruuduissa pienempi kuin normaaliannoksen saaneissa. Täten satotoiveita ajatellen ei ole 
mitaaăn syytă ylisuurien torjunta-aineiden kăyttooonn. Tahattoman yliannostuksen vălttämiseksi ruiskujen kuntoon olisi kiinnitettävă huomiota, erityisesti herbisidien kohdalla.

Torjunta-aineet sekă normaalimäärin ettă ylisuurin vaikuttivat jossain määrin mikrobeihin ja niiden aktiivisuuteen. Vaikutukset olivat yleensă tilapäisiä ja tavallisesti aktiivisuutta alentavia. Ureolyyttiset bakteerit ja maan dehydrogenaasiaktiivisuus olivat herkimpiä. Nämä vaikutukset voidaan katsoa merkiksi liian korkeista ja py- syvistă torjunta-ainejäămistă. Torjunta-aineiden hajoamista voitaisiin nopeuttaa lisảämällă maan yleistă mikrobiologista aktiivisuutta. Samạlla maan mururakenne paranisi.

Olisi syytă selvittăă jatkossa keinoja, joilla sokerijuurikasmaiden yleistä mikrobiologista aktiivisuutta voitaisiin kohottaa. Mahdollisia keinoja voisivat olla orgaaniset aineet (naatit, kohtuullinen määră olkia ym.) sekä erilaiset viljelykierrot sisăltăen mahdollisesti myös nurmen. 